\title{
PENINGKATAN KETERAMPILAN WIRAUSAHA TUNE UP DAN CUCI MOTOR BAGI PARA PEMUDA PUTUS SEKOLAH DI KOTA KEDIRI
}

\author{
Dani Irawan ${ }^{1)}$, Rahayu Mekar Bisono ${ }^{2)}$ \\ 1)Perawatan dan Perbaikan Mesin Politeknik Kediri \\ E-mail: the_boymaster2@yahoo.com \\ ${ }^{2)}$ Perawatan dan Perbaikan Mesin Politeknik Kediri \\ E-mail: rahayuyudhaputra@gmail.com
}

\begin{abstract}
Abstrak
Program kegiatan Pengabdian Kepada Masyarakat ini bertujuan untuk: 1) Memberikan pelatihan keterampilan wirausaha tune up dan cuci motor bagi pemuda putus sekolah di Kota Kediri, 2) Melaksanakan kegiatan praktik wirausaha tune up dan cuci motor bagi pemuda putus sekolah di Kota Kediri. Kesimpulan kegiatan pengabdian masyarakat, sebagai berikut: proses belajar Peserta Pelatihan dalam implementasi alternative model pembelajaranketerampilan vokasional teknologi otomotif melalui pendekatan pembelajaran latihan keterampilan dengan demonstrasi memiliki kecenderungan perkembangan yang meningkat setiap fasenya. Peserta Pelatihan dalam proses belajar lebih dapat memahami materi yang diharapkan dapat tercapai dan hasil belajar Peserta Pelatihan dalam pembelajaran. Ketercapaian waktu bidang Tune Up sepeda motor pada Peserta Pelatihan pada setiap fase-nya mengalami peningkatan. Perubahan rata-rata ketercapaian waktu pada praktik Tune Up yang dilaksanakan Peserta Pelatihan menunjukan rata-rata peningkatan yang stabil. Hasil belajar bidang Tune Up pada Peserta Pelatihan dengan menggunakan metode demonstrasi mengalami peningkatan setiap fase-nya.
\end{abstract}

Kata Kunci: Pelatihan, Wirausaha, Tune up, Pemuda Putus Sekolah

\section{PENDAHULUAN}

\subsection{Analisis Situasi}

Beberapa faktor penyebab terjadinya kecelakaan di jalan raya adalah faktor pengemudi, infrastruktur jalan, dan kendaraan. Faktor pengemudi misalkan saja mengendarai kendaraan dalam keadaan mengantuk, mabuk, atau mengendarai tanpa mematuhi peraturan keselamatan berlalulintas. Sedangkan faktor infrastruktur jalan yaitu kualitas jalan yang jelek, banyak lubang, atau daya tampungnya tidak sesuai dengan jumlah kendaraan yang melaluinya. Sementara faktor kendaraan yaitu rem yang tidak bekerja, ban aus, kemudi yang sudah tidak bekerja dengan normal, dan kerusakan pada bagian-bagian yang menyebabkan kendaraan sulit dikendalikan sesuai dengan keinginan pengendara. Kerusakan- kerusakan yang terjadi pada kendaraan dan tidak segera diatasi menjadi salah satu faktor penyebab terjadinya kecelakaan.

Hal ini mengacu data dari AISI (Asosisasi Industri Sepeda Motor Indonesia), hingga Juni 2010 jumlah penjualan sepeda motor mencapai 40 Juta Unit dan mengalami peningkatan prosentase sekitar $12.5-15 \%$ pertahun. Pertumbuhan jumlah sepeda motor yang sangat pesat diikuti dengan pertumbuhan jumlah kecelakaan yang tinggi pula. Kecelakaan kendaraan dijalan raya didominasi oleh pengendara sepeda motor yaitu sebesar $70 \%$.

Kondisi kendaraan yang tidak normal menjadi salah satu faktor penyebab terjadinya kecelakaan. Akan tetapi pemilik kendaraan masih sering mengabaikan 
kerusakan yang terjadi pada kendaraannya dan tidak segera melakukan perbaikan. Kendaraan yang rusak akan tetapi tidak segera diperbaiki disebabkan faktor keuangan, faktor ketersediaan bengkel, dan faktor ketidaktahuan pemilik kendaraan.

Menurut data AISI, jumlah bengkel resmi Honda: 3.800 AHASS, Yamaha: 2.750 YSS, dan Suzuki: 1.400. Jumlah totalnya iika ditambah dengan bengkel kawasaki, Piagio, TVS, Bajaj, Minerva, dan KTM masih di bawah 10.000 bengkel. Bengkel- bengkel tersebut adalah bengkel resmi yang tergabung atau mendapatkan lisensi dari Agen Tunggal Pemegang Merk (ATPM). Jika perbandingan antara jumlah bengkel resmi dengan yang diluar ATPM adalah 1:5, maka jumlah bengkel sepeda motor adalah 50.000 bengkel.

Dengan demikian, perbandingan antara jumlah kendaraan dengan bengkel untuk perbaikan adalah: 50.000: 40.000 .000 atau 1:800. Artinya 1 bengkel melayani 800 sepeda motor. Sebagai dampaknya, pemilik kendaraan harus antri dalam melakukan perawatan kendaraan dan mengabaikan kerusakan yang terjadi. Sedangkan kerusakan kendaraan akan tetap jika tidak segera dilakukan perbaikan karena faktor ketidaktahuan pemilik kendaraan juga banyak terjadi. Walaupun setiap sepeda motor yang dijual dari dealer dilengkapi dengan petunjuk perawatan sederhana, akan tetapi karena tidak memiliki ketrampilan teknisnya maka pemilik kendaraan juga tidak pernah melakukan perawatan sesuai dengan ada yang dibuku petunjuk. Akibatnya, kita dapat dengan mudah menemukan sepeda motor dengan kondisi rem yang tidak standar, ban aus atau tekananya tidak sesuai spesifikasi, lampu indikatornya mati, kopling berat, stang tidak stabil dan berbagai kerusakan lain yang dapat membahayakan pemilik kendaraan saat mengendarainya di jalan.

Berdasarkan data yang diperoleh dari BPS Sakernas tahun $201643 \%$ dari total pengangguran adalah lulusa SMK/ SMA yang tidak melanjutan atau putus sekolah.
Hal ini berarti jumlah pemuda yang putus sekolah dan berada pada usia produktif kerja cukup tinggi. Kondisi ini jika dibiarkan dapat menyebabkan penumpukan pengangguran dan menimbulkan masalah sosial baru. Kegiatan peningkatan wirausaha tune up dan cuci motor perlu diadakan berdasarkan latar belakang yang dipaparkan diatas. Kegiatan yang dilakukan diharapkan dapat melatih pemilik kendaraan sepeda motor sehingga mampu melakukan perawatan ringan secara mandiri dan meningkatkan wirausaha. Kegiatan lain yang dilakukan dalam kegiatan pengabdian ini adalah servis gratis juga menjadi salah satu bentuk implementasi ilmu oleh peserta pelatihan yang dikembangkan dan memberikan manfaat secara langsung kepada masyarakat

\subsection{Justifikasi Permasalahan}

Berdasarkan analisis yang telah dipaparkan di atas, permasalahan yang dihadapi oleh sasaran kegiatan ini dapat diidentifikasi sebagai berikut:

1) Besarnya jumlah pengangguran adalah lulusan SMK/ SMA yang tidak melanjutan atau putus sekolah Kecelakaan kendaraan didominasi oleh sepeda motor yaitu sebesar $70 \%$.

2) Pemilik sepeda motor belum memiliki ketrampilan untuk melakukan perawatan ringan terhadap sepeda motornya.

3) Jumlah bengkel perawatan dan perbaikan sepeda motor tidak sebanding dengan jumlah sepeda motor yang ada.

4) Adanya peluang untuk membuka usaha tuneup

\subsection{Tujuan Kegiatan}

Kegiatan Pelatihan Perawatan dan Servis Gratis Sepeda Motor bertujuan untuk:

1. Memberikan pelatihan keterampilan wirausaha tune up dan cuci motor bagi pemuda putus sekolah di Kota Kediri

2. Melaksanakan kegiatan praktik wirausaha tune up dan cuci motor bagi pemuda putus sekolah di Kota Kediri. 


\subsection{Luaran Penelitian}

1. Peningkatan keterampilan dalam melakukan cuci sepeda motor dan tune up sebagai modal untuk berwirausaha

2. Publikasi Ilmiah

\section{METODE PELAKSANAAN}

Metode yang digunakan adalah ceramah, Tanya jawab dan praktik langsung yang dijabarkan sebagai berikut:

Pertama, pelaksanaan kegiatan ini dimulai dengan menganalisis permasalahan yang dihadapi dimana $70 \%$ kecelakaan terjadi pada pengendara sepeda motor. Hasil yang ditemukan adalah bahwa faktor penyebab kecelakaan adalah karena kurangnya pengetahuan berkendaraan yang aman dan kendaraan yang tidak normal/ mengalami kerusakan akan tetapi tetapdipergunakan. Kendaraan yang tidak normal/mengalami kerusakan dikarenakan perbandingan antara bengkel dengan sepeda motor adalah 1:800 sehingga tidak semua sepeda motor terlayani oleh bengkel dengan baik. hal ini menjadi peluang usaha yang masih terbuka lebar. Kemudian masalah kedua adalah jumlah pengangguran pemuda putus sekolah yang masih tergolong besar perlu penangnan yang sesuai untuk mengurangi pengangguran.

Kedua, Pemecahan masalah yang diajukan berdasarkan uraian diatas secara operasional adalah mengadakan pelatihan wirausaha tune up dan cuci sepeda motor bagi warga masyarakat pemilik sepeda motor. Pelatihan yang dilakukan mencangkup materi pengetahuan teknik berkendaraan yang aman dan pelatihan perawatan ringan sepeda motor. Kegiatan dilaksanakan selama 2 hari dengan target sasaran sebanyak 20 peserta. Setiap harinya akan dilakukan pelatihan dan servis sepeda motor dengan jumlah minimal 10 peserta. Peserta pelatihan adalah pemiliki kendaraan yang mengikutsertakan kendaraan dalam servis sepeda motor.
Ketiga Setelah pelatihan, diharapkan $100 \%$ peserta memiliki pengetahuan dan ketrampilan melakukan perawatan dan perbaikan ringan sepeda motor. Kegiatan pelatihan ini diharapkan dapat menyumbang penurunan angka pengangguran di kota Kediri

\section{HASIL PEMBAHASAN KEGIATAN}

\subsection{Pelaksanaan Tune Up Sepeda Motor}

Hasil data yang dihasilkan melalui tes keterampilan yang memakai satuan ukuran variabel berupa persentase. Perubahan yang terjadi setelah tes keterampilan menunjukan rata-rata persentase kerja Peserta Pelatihan pada keterampilan Tune Up sepeda motor menunjukan rata-rata peningkatan dari fase baseline (A1), ke fase baseline (A2). Fase baseline (A1) dan fase baseline (A2) Peserta Pelatihan 1 dan 2 pada Tabel 1 dan 2.

Ketercapaian waktu Peserta Pelatihan pada fase baseline (A1) Peserta Pelatihan 1 menunjukan angka melebihi 720 detik (12 menit). Peserta Pelatihan 1 pada tahap baseline A1 belum terlalu paham terhadap apa yang akan dilakukannya sehingga pada tahap ini Peserta Pelatihan kebingungan yang berakibat pada ketidaksesuaian waktu yang dicapainya. Keterampilan Tune Uppada sepeda motor pun tidak berjalan maksimal karena Peserta Pelatihan 1 tidak dapat menyelesaikannya (Syah, 2010). Peserta Pelatihan 1 lebih banyak diam pada tahapan ini sehingga ketercapaian waktunya melebihi standar yang telah ditetapkan, yang pada akhirnya Peserta Pelatihan 1 menyerah karena belum memahami keterampilan ini. Rata-rata ketercapaian waktu yang didapat oleh Peserta Pelatihan 1 pada tahap baseline (A1) sebesar 930 detik.

Ketercapaian waktu Peserta Pelatihan pada fase baseline (A2) Peserta Pelatihan 1 menunjukan peningkatan, hal ini dikarenakan pada fase baseline (A2) Peserta Pelatihan telah mendapatkan intervensi sebelum tahap ini berlangsung. Peserta Pelatihan 1 pada tahap ini dapat menyelesaikan pekerjaannya dengan baik 
Dani dkk. Peningkatan Keterampilan Wirausaha Tune Up Dan Cuci Motor Bagi Para Pemuda Putus Sekolah Di Kota Kediri

hanya saja waktu yang dicapai oleh Peserta Pelatihan 1 ini belum maksimal. Terdapat beberapa tahapan yang masih diluar ketercapaian waktu tetapi waktu yang didapat sudah jauh lebih baik dibandingkan dengan tahap baseline (A1). Rata-rata ketercapaian waktu yang didapat oleh Peserta Pelatihan 1 pada tahap baseline (A2) sebesar 719,25 detik. Ketercapaian waktu Peserta Pelatihan pada fase baseline (A1) Peserta Pelatihan 2 menunjukan angka melebihi 720 detik (12 menit). Peserta Pelatihan 2 pada tahap baseline A1 belum terlalu paham terhadap apa yang akan dilakukannya sehingga pada tahap ini
Peserta Pelatihan kebingungan yang berakibat pada ketidaksesuaian waktu yang dicapainya. Keterampilan Tune Up pada sepeda motor pun tidak berjalan maksimal karena Peserta Pelatihan 2 tidak dapat menyelesaikannya. Peserta Pelatihan 2 lebih banyak diam pada tahapan ini sehingga ketercapaian waktunya melebihi standar yang telah ditetapkan, yang pada akhirnya Peserta Pelatihan 2 menyerah karena belum memahami keterapilan ini. Rata-rata ketercapaian waktu yang didapat oleh Peserta Pelatihan 2 pada tahap baseline (A1) sebesar 944.5 detik.

Tabel 1. Rata-rata persentase kerja baseline Pertama

\begin{tabular}{|c|c|c|c|c|c|c|c|c|c|}
\hline \multirow{3}{*}{$\begin{array}{l}\text { PROSES } \\
\text { KERJA }\end{array}$} & \multicolumn{8}{|c|}{ WAKTU KERJA } & \multirow{3}{*}{$\begin{array}{l}\text { RATA- } \\
\text { RATA }\end{array}$} \\
\hline & \multicolumn{2}{|l|}{1} & \multicolumn{2}{|l|}{2} & \multicolumn{2}{|l|}{3} & \multicolumn{2}{|l|}{4} & \\
\hline & A1 & A2 & A1 & A2 & A1 & A2 & A1 & A2 & \\
\hline 1 & $33,4 \%$ & $33,4 \%$ & $33,4 \%$ & $33,4 \%$ & $33,4 \%$ & $33,4 \%$ & $33,4 \%$ & $33,4 \%$ & $33,4 \%$ \\
\hline 2 & $40 \%$ & $100 \%$ & $40 \%$ & $80 \%$ & $40 \%$ & $80 \%$ & $40 \%$ & $80 \%$ & $40 \%$ \\
\hline 3 & $33,3 \%$ & $83,4 \%$ & $83,4 \%$ & $100 \%$ & $66,7 \%$ & $100 \%$ & $66,7 \%$ & $100 \%$ & $50 \%$ \\
\hline 4 & $0 \%$ & $0 \%$ & $0 \%$ & $100 \%$ & $0 \%$ & $100 \%$ & $0 \%$ & $100 \%$ & $0 \%$ \\
\hline
\end{tabular}

Tabel 2. Rata-rata persentase kerja baseline Kedua

\begin{tabular}{|c|c|c|c|c|c|c|c|c|c|}
\hline \multirow{3}{*}{$\begin{array}{l}\text { PROSES } \\
\text { KERJA }\end{array}$} & \multicolumn{8}{|c|}{ WAKTU KERJA } & \multirow{3}{*}{$\begin{array}{l}\text { RATA- } \\
\text { RATA }\end{array}$} \\
\hline & \multicolumn{2}{|c|}{1} & \multicolumn{2}{|l|}{2} & \multicolumn{2}{|l|}{3} & \multicolumn{2}{|l|}{4} & \\
\hline & A1 & $\mathrm{A} 2$ & A1 & $\mathrm{A} 2$ & A1 & $\mathrm{A} 2$ & A1 & $\mathrm{A} 2$ & \\
\hline 1 & $33,4 \%$ & $33,4 \%$ & $33,4 \%$ & $33,4 \%$ & $33,4 \%$ & $33,4 \%$ & $33,4 \%$ & $33,4 \%$ & $33,4 \%$ \\
\hline 2 & $40 \%$ & $100 \%$ & $60 \%$ & $80 \%$ & $60 \%$ & $80 \%$ & $60 \%$ & $80 \%$ & $55,4 \%$ \\
\hline 3 & $33,3 \%$ & $83,4 \%$ & $83,4 \%$ & $100 \%$ & $33,3 \%$ & $100 \%$ & $50 \% \%$ & $100 \%$ & $55 \%$ \\
\hline 4 & $0 \%$ & $0 \%$ & $0 \%$ & $100 \%$ & $0 \%$ & $100 \%$ & $0 \%$ & $100 \%$ & $0 \%$ \\
\hline
\end{tabular}

Tabel 3. Rata-rata persentase kerja baseline Ketiga

\begin{tabular}{|c|c|c|c|c|c|c|c|c|c|}
\hline \multirow{3}{*}{$\begin{array}{l}\text { PROSES } \\
\text { KERJA }\end{array}$} & \multicolumn{8}{|c|}{ WAKTU KERJA } & \multirow{3}{*}{$\begin{array}{l}\text { RATA- } \\
\text { RATA }\end{array}$} \\
\hline & \multicolumn{2}{|l|}{1} & \multicolumn{2}{|l|}{2} & \multicolumn{2}{|l|}{3} & \multicolumn{2}{|l|}{4} & \\
\hline & A1 & $\mathrm{A} 2$ & A1 & $\mathrm{A} 2$ & A1 & $\mathrm{A} 2$ & A1 & $\mathrm{A} 2$ & \\
\hline 1 & $33,4 \%$ & $33,4 \%$ & $33,4 \%$ & $33,4 \%$ & $33,4 \%$ & $33,4 \%$ & $0 \%$ & $0 \%$ & $33,4 \%$ \\
\hline 2 & $40 \%$ & $40 \%$ & $60 \%$ & $85 \%$ & $85 \%$ & $85 \%$ & $45 \%$ & $45 \%$ & $55,4 \%$ \\
\hline 3 & $50 \%$ & $50 \%$ & $83,4 \%$ & $95 \%$ & $95 \%$ & $95 \%$ & $45,85 \%$ & $45,85 \%$ & $55 \%$ \\
\hline
\end{tabular}

Ketercapaian waktu Peserta Pelatihan pada fase baseline (A2) Peserta Pelatihan 2 menunjukan peningkatan, hal ini dikarenakan pada fase baseline (A2) Peserta Pelatihan telah mendapatkan intervensi sebelum tahap ini berlangsung (Jama, 2008). Peserta Pelatihan 2 pada tahap ini dapat menyelesaikan pekerjaannya dengan baik hanya saja waktu yang dicapai oleh Peserta Pelatihan 2 ini belum maksimal. Terdapat beberapa tahapan yang masih diluar ketercapaian waktu tetapi waktu yang didapat sudah jauh lebih baik dibandingkan dengan tahap baseline (A1). Rata-rata ketercapaian waktu yang didapat oleh Peserta Pelatihan 1 pada tahap baseline (A1) sebesar 750,25 detik.

Analisis dalam kondisi kemampuan keterampilan Tune Up pada penelitian ini 
terdiri dari empat kondisi fase baseline (A1), lima kondisi fase intervensi (B) dan 4 kondisi fase baseline (A2). Analisis dalam kondisi meliputi: panjang kondisi; estimasi kecenderungan arah; kecenderungan stabilitas; jejak data; level stabilitas dan rentang; level perubahan; dan rangkuman hasil analisis dalam kondisi.

Semua Peserta Pelatihan memiliki estimasi kecenderungan yang berubah mulai dari fase baseline A1 sebelum dilakukan intervensi kemampuan Tune Up Peserta Pelatihan satu dan Peserta Pelatihan dua mendatar. Estimasi kecenderungan arah pada fase intervensi $B$ memiliki kecenderungan arah meningkat. Begitu juga pada fase baseline A2 setelah dilakukannya intervensi menggambarkan kecenderungan meningkat. Stabilitas data pada kemampuan keterampilan Tune Up kedua Peserta Pelatihan menunjukan arah positif $(+)$. Artinya perubahan kemampuan keterampilan yang dimiliki Peserta Pelatihan mengarah pada arah positif atau membaik (Suryosubroto, 2002). Perubahan level yang meningkat menggambarkan bahwa penggunaan metode demonstrasi dalam proses belajar Tune Up memiliki pengaruh baik atau positif. Hasil analisis antar kondisi ditunjukan dengan data overlap yang membandingkan data fase baseline A1 sebelum dilakukan intervensi dengan fase intervensi $\mathrm{B}$ menunjukan nilai data terendah adalah $20 \%$. Artinya semakin kecil nilai overlap brarti intervensi yang telah dilakukan berpengaruh terhadap target behavior berupa kemampuan keterampilan Tune Upsepeda motor pada Peserta Pelatihan.

Intervensi yang telah diberikan pada Peserta Pelatihan berupa pembelajaran keterampilan otomotif menggunakan metode demonstrasi berdampak positif atau baik terhadap perilaku Peserta Pelatihan. Penggunaan metode demonstrasi pada anak tuna rungu dirasa sangat tepat. Peserta Pelatihan tuna rungu memiliki keterbatasan dalam berkomunikasi dan metode demonstrasi memudahkan Peserta Pelatihan memahami materi pembelajaran melalui praktik langsung pada sepeda motor (Slameto, 2013).

Analisis durasi belajar keterampilan menghasilkan data ketercapaian waktu bidang keahlian Tune Upsepeda motor pada Peserta Pelatihan pada setiap fase mengalami peningkatan. Perubahan ratarata ketercapaian waktu pada praktik Tune Upyang dilaksanakan Peserta Pelatihan menunjukan rata-rata peningkatan yang stabil dari fase baseline (A1), ke fase baseline (A2). Rata-rata ketercapaian waktu proses kerja untuk Peserta Pelatihan 1 adalah sebesar 12,23 menit dan 11,12 menit pada Peserta Pelatihan 2. Kemudian data tersebut apabila dibandingkan dengan waktu rata-rata normal Tune Upyaitu selama 12 menit. Ketercapaian waktu Peserta Pelatihan tunarungu dalam bidang keahlian Tune Uptidak jauh berbeda dengan orang normal. Peserta Pelatihan tunarungu dalam pembelajarannya hanya terkendala pada aspek komunikasi atau penangkapan informasi namun dalam pelaksanaan praktik tidak jauh berbeda.

\subsection{Pelaksanaan Keterampilan Mencuci Motor}

Pembelajaran keterampilan mencuci sepeda motor merupakan suatu kegiatan untuk menghasilkan jasa pencucian sepeda motor yang mengubah kondisi sepeda motor yang kotor menjadi bersih. Tujuan pembelajaran yang ingin dicapai oleh Peserta Pelatihan terhadap keterampilan mencuci sepeda motor adalah untuk menyiapkan dan melatih Peserta Pelatihan dalam keterampilan mencuci sepeda motor secara benar, bersih, dan rapi. Melalui pembelajaran ini Peserta Pelatihan dapat mengetahui tahapan proses mencuci sepeda motor dari awal hingga akhir sehingga dapat menjadi bekal keterampilan untuk diterapkan pada dunia kerja di masyarakat. Oemar Hamalik (2011: 58-65) berpendapat bahwa tujuan pembelajaran adalah sebagai berikut:

a. Mengajar adalah upaya menyampaikan pengetahuan kepada peserta didik/Peserta Pelatihan di sekolah. 
b. Mengajar adalah mewariskan kebudayaan kepada generasi muda melalui lembaga pendidikan sekolah.

c. Pembelajaran adalah upaya mengorganisasi lingkungan untuk menciptakan kondisi belajar bagi peserta didik.

d. Pembelajaran adalah upaya mempersiapkan peserta didik untuk menjadi warga masyarakat yang baik.

Berdasarkan hasil penelitian dan kajian teori yang ada maka tujuan pembelajaran keterampilan mencuci sepeda motor yang ingin dicapai oleh Peserta Pelatihansudah benar yaitu Instruktur menyampaikan pengetahuan keterampilan mencuci sepeda motor kepada Peserta Pelatihan, mempersiapkan peserta didik untuk menjadi warga masyarakat yang baik, serta membantu Peserta Pelatihan menghadapi kehidupan masyarakat sehari-hari.

Pertemuan pertama tanggal 13 Oktober 2017 di halaman depan ruang kelurahan Mojoroto keterampilan otomotif dilaksanakan. Didapatkan bahwa subyek masih memerlukan banyak pengarahan dan pendampingan dari Instruktur.Pada pertemuan ini Instruktur memulai pembelajaran dengan mengkondisikan situasi pembelajaran, mengkondisikan Peserta Pelatihan, menyampaikan materi pembelajaran mencuci sepeda motor. Instruktur menunjukkan dan menjelaskan nama serta fungsi peralatan yang digunakan dalam pembelajaran mencuci sepeda motor, Peserta Pelatihan diminta untuk menyebutkan kembali nama dan fungsi peralatan yang ditunjuk oleh Instruktur. Peralatan yang digunakan dalam pembelajaran mencuci sepeda motor meliputi kompresor, mesin penyemprot sabun (steam) selang air, mesin penyemprot air, ember, sabun cuci mobil/motor, pengkilat bodi motor, pengkilat ban mobil/motor, spons, kanebo dan lap kain lembut.

Setelah tahap persiapan peralatan selesai, Instruktur memulai memberikan contoh atau model tahapan mencuci sepeda motor yang benar. Peserta Pelatihan kemudian diminta melaksanakan praktik mencuci sepeda motor dengan bimbingan dan pendampingan dari Instruktur. Sebagian Peserta Pelatihan sudah dapat melaksanakan praktik mencuci sepeda motor sesuai dengan langkah-langkah yang dicontohkan oleh Instruktur, namun banyak hambatan yang membuat Peserta Pelatihan kadang tidak dapat menyelesaikan pekerjaan tersebut dengan baik. Tahapan mencuci sepeda motor yaitu menyemprot seluruh bagian sepeda motor menggunakan air bersih untuk menghilangkan kotoran dan debu yang menempel, mengusapkan shampoo khusus untuk kendaraan bermotor yang sudah dicampur dengan air, gunakan spons untuk meratakan shampoo, meratakan shampoo dilakukan mulai dari bagian atas hingga bagian bawah sepeda motor, semprot kembali bagian- bagian sepeda motor yang sudah dibersihkan dengan menggunakan shampoo hingga sisa sabun hilang dan benar-benar bersih, selanjutnya adalah proses pengeringan menggunakan lap bersih dan halus.

Pertemuan kedua dilaksanakan tanggal 17 Oktober 2017, Instruktur masih memberi pendampingan dari awal hingga akhir. Pada pertemuan ini Instruktur memulai pembelajaran dengan mengkondisikan situasi pembelajaran, mengkondisikan Peserta Pelatihan,menyampaikan materi pembelajaran mencuci sepeda motor. Instruktur memulai memberikan contoh atau model tahapan mencuci sepeda motor yang benar. Kemudian Peserta Pelatihan diminta untuk melakukan praktik mencuci sepeda motor. Pada pertemuan kedua ini subyek memulai praktik dengan membawa sepeda motor dari parkiran ke tempat pencucian, menempatkan sepeda motor dengan standar satu, kemudian subyek memulai menyemprotkan air ke seluruh bagian sepeda motor, lalu menyemprotkan shampoo menggunakan mesin steam meratakannya menggunakan spons. Subyek meratakan shampoo dari bagian depan atas hingga belakang bawah sepeda motor. Setelah itu subyek kemudian membilasnya dengan air bersih, mengeringkan bagian-bagian sepeda motor 
menggunakan kanebo, dan yang terakhir adalah memoles body sepeda motor menggunakan kit. Pada pertemuan ini Peserta Pelatihan mencuci dua unit sepeda motor milik Instruktur.

Pertemuan ketiga pada tanggal 1 Oktober 2017, subyek masih diarahkan oleh Instruktur pada beberapa bagian saja. Subyek mengalami kemajuan dalam proses mencuci sepeda motor. Subyek terlihat lebih telaten dalam mengerjakan tugasnya sehingga hasilnya juga cukup bersih dan rapi. Hanya saja terkadang subyek mengerjakan tugas sambil mengobrol dengan temannya sehingga terdapat beberapa bagian yang terlewatkan untuk dibilas dan tidak menyemir ban sepeda motor.

Pertemuan keempat pada tanggal 10 Oktober 2017, subyek sudah memperlihatkan kemajuan yang cukup baik dengan tidak lagi banyak diberi pengarahan dan pendampingan dari Instruktur. Instruktur hanya memperhatikan subyek melaksanakan praktik dan memberikan bimbingan pada Peserta Pelatihan lain. Waktu pengerjaan mencuci sepeda motor pada pertemuan keempat ini menjadi lebih cepat sehingga dapat mencuci tiga unit sepeda motor pada pertemuain ini, Instruktur hanya mengawasi saja dan sesekali memberi arahan untuk mengingatkan jika ada yang terlewatkan. Pengerjaan tugas mencuci sepeda motor sudah lebih baik dibandingkan dengan pertemuan sebelumnya, hasil lebih bersih dan rapi serta tidak terlupa ban untuk disemir.

\section{KESIMPULAN}

Kesimpulan kegiatan pengabdian masyarakat, sebagai berikut: Ketercapaian waktu bidang Tune Up sepeda motor pada Peserta Pelatihan pada setiap fase-nya mengalami peningkatan. Perubahan ratarata ketercapaian waktu pada praktik Tune Up yang dilaksanakan Peserta Pelatihan menunjukan rata-rata peningkatan yang stabil. Hasil belajar bidang Tune Up pada
Peserta Pelatihan dengan menggunakan metode demonstrasi mengalami peningkatan setiap fase-nya.

Pembelajaran keterampilan mencuci sepeda motor Peserta Pelatihan sudah cukup baik, Instruktur dapat mengenal karakteristik setiap peserta didik, Instruktur melaksanakan pembelajaran sesuai dengan silabus, Instruktur memulai pembelajaran dengan penyampaian tujuan dan materi pembelajaran, Instruktur memberikan contoh praktik mencuci sepeda motor sebelum Peserta Pelatihan melakukan praktik. Materi yang diberikan meliputi pengenalan peralatan, mempersiapkan peralatan, cara menggunakan peralatan, dan langkah-langkah mencuci sepeda motor. Strategi yang digunakan oleh Instruktur dalam menyampaikan materi pembelajaran keterampilan mencuci sepeda motor adalah dengan metode ceramah dan pemberian contoh sehingga Peserta Pelatihan dapat mengikuti pembelajaran dengan baik. Peserta Pelatihan sangat antusias untuk mengikuti pembelajaran keterampilan mencuci sepeda mtotor, Peserta Pelatihan mampu melaksanakan pembelajaran dengan baik, Peserta Pelatihan membantu Instruktur untuk mempersiapkan peralatan, Peserta Pelatihan mampu menyebutkan nama alat serta cara menggunakan peralatan mencuci sepeda motor, Peserta Pelatihan mampu melakukan praktik dengan runtut. Tujuan pembelajaran keterampilan mencuci sepeda motor yaitu memberikan pelatihan keterampilan dan pengalaman bagi Peserta Pelatihan sehingga dapat menjadi bekal untuk bekerja di masyarakat dikemudian hari.

\section{SARAN}

1. Pelaksanaan pembelajaran keterampilan mencuci sepeda motor sebaiknya dibuat perencanaan pembelajaran berupa rencana pelaksanaan pembelajaran sehingga tujuan pembelajaran dapat dicapai sesuai dengan perencanaan.

2. Untuk kegiatan lanjutan perlu adanya evaluasi sesuai dengan standar yang sudah ditentukan sehingga dapat 
Dani dkk. Peningkatan Keterampilan Wirausaha Tune Up Dan Cuci Motor Bagi Para Pemuda Putus Sekolah Di Kota Kediri

digunakan sebagai acuan untuk meningkatkan kualitas pembelajaran yang sudah ada.

\section{UCAPAN TERIMA KASIH}

Kegiatan pengabdian masyarakat yang telah dilaksanakan telah dapat diselesaikan dengan dan didapat hasil yang diharapkan dapat diadopsi oleh masyarakat. Dalam pelaksanaan kegiatan ini, tim peneliti banyak mendapat bantuan dari bebagai kalangan, sehingga kegiatan pengabdian ini dapat terlaksana. Sehubungan dengan hal tersebut, tim peneliti mengucapkan terima kasih kepada LPPM USU yang telah membiayai kegiatan ini.

\section{DAFTAS PUSTAKA}

Astra Honda Training Center. 2015. Pelatihan Mekanik Tingkat I. Modul.

Ibnu Peserta Pelatihannto.2013. Kesiapan Peserta Pelatihan kelas III SMKN 2 Depok mengikuti Uji Kompetensi Otomotif Tune Up. Skripsi. FT UM

Jama, J. 2008. Teknik sepeda motor jilid 2 untuk SMK. Jakarta: Departemen Pendidikan Nasional.

Oemar Hamalik. 2011. Kurikulum dan Pembelajaran. Jakarta: PT Bumi Aksara. Pendidikan Nasional, Direktorat Jenderal Pendidikan Tinggi, DirektoratKeteragaan.

PT. Astra Honda Motor.2015. Buku Pedoman Pemilik Honda. Jakarta.

Slameto. .2013. Belajar dan faktor-faktor yang mempengaruhinya. Jakarta: Rineka Cipta.

Suryosubroto, B. 2002. Beberapa aspek dasardasar kependidikan. Jakarta: PT. Rineka Cipta. 